\title{
Contribution in the Study of the Durability of Plaster Mortar Based on Sand of Dunes Reinforced by Date Palm Fibers
}

\author{
Rachedi Mokhtar*, Kriker Abdelouahed and Mokhtari Abdessamed \\ Laboratory Exploitation and Valorization of Natural Resources in Arid Zones, Kasdi Merbah Ouargla University, Algeria
}

Submission: March 3, 2018; Published: May 09, 2018

*Corresponding author: Rachedi Mokhtar, Laboratory Exploitation and Valorization of Natural Resources in Arid Zones, Kasdi Merbah Ouargla University, BP 511 Ouargla 30000, Algeria, Email: mokedi@hotmail.fr

\begin{abstract}
The aim of this study is the use of local materials (plaster, sand dunes and date palm fiber) for the region of southern Algeria. By expand areas of the use of these materials in the field of construction. Despite the large ament of gypsum, its use is limited to some secondary operations like coatings and decorative elements. The sand dunes and palm fiber, its use in the construction are very limited. In this study, the sand dunes and palm fiber was added to plaster, to find the mortar that has physical and mechanical properties that allow its use in construction. The results obtained showed that the addition of date palm fibers improves the physical properties (density, water absorption, etc.) and mechanical properties (compression strength, flexural strength, etc.).
\end{abstract}

Keywords: Plaster; Sand dunes; Date palm fibers; Compression strength; Flexural strength

\section{Introduction}

The Algeria, especially the South, is rich in natural materials, which can then be used directly in the construction field he must study their properties in order to extend their use. Among these materials, which can be exploited, and that we will consider, plaster, sand dune, and the fibers of the Palm. The use of vegetable fibers in the reinforcement of building materials to improve certain properties, it is the most used technology currently, because these results and to expand the use of eco-materials. Algeria has unlimited sources of vegetable fibers (of Palm, Alfa Abaca, hemp, Cotton,...), but their use in the construction of the almost non-existent field.

The incorporation of the fibers of date palm in the mortar of plaster, is carried out in order to improve the tensile strength and decrease its fragility. The major assumption that the fibers allow the judgment of the cracking mechanism, delaying the start of the crack and the controlling once it appears. In our study, we will examine the effect of the addition of fibers of palm trees date palm to the physical and mechanical properties of the Mortar plaster. Where we are looking at the impact of the rate and length of the fibers of date palm on the characteristics of mortar plaster, in the short and in the long term.

\section{Materials Used}

The materials used are those available at the local level:

\section{Sand dunes used}

In our study we used the sand dunes of GUERRARA (GHARDAIA).

The physical properties of sand dunes used are represented in Table 1.

Table 1: The physical properties of sand dunes.

\begin{tabular}{|c|c|c|c|c|}
\hline $\begin{array}{c}\text { The } \\
\text { apparent } \\
\text { volumic } \\
\text { mass } \rho_{a} \\
\left(\mathbf{k g} / \mathbf{m}^{3}\right)\end{array}$ & $\begin{array}{c}\text { The } \\
\text { volumique } \\
\text { absolute } \\
\text { mass } \rho_{s} \\
\left(\mathbf{k g} / \mathbf{m}^{3}\right)\end{array}$ & $\begin{array}{c}\text { Fodule } \\
M_{F}\end{array}$ & $\begin{array}{c}\text { Equivalent } \\
\text { of sand } \\
\text { visual } \\
E_{S p}(\%)\end{array}$ & $\begin{array}{c}\text { Equivalent } \\
\text { of sand to } \\
\text { the piston } \\
E_{S p}(\%)\end{array}$ \\
\hline 1489 & 2563 & 1.19 & 93.6 & 91.8 \\
\hline
\end{tabular}

\section{Mixing water}

The used mixing water is the public drinking water of the network of the city of Ghardaiia.

\section{Lime}

Air lime as a retardant of setting time of the plaster was used, because it decreases the solubility of the latter and allows increasing the time of employment. In addition it does not affect these mechanical properties. 


\section{Civil Engineering Research Journal}

A chemical analysis of the lime used was performed using the University of Laghouat, the results of this technique are the method of diffractometer by X-rays in the lab. Physics at presented on the diffractogramme below [1] (Figure 1).

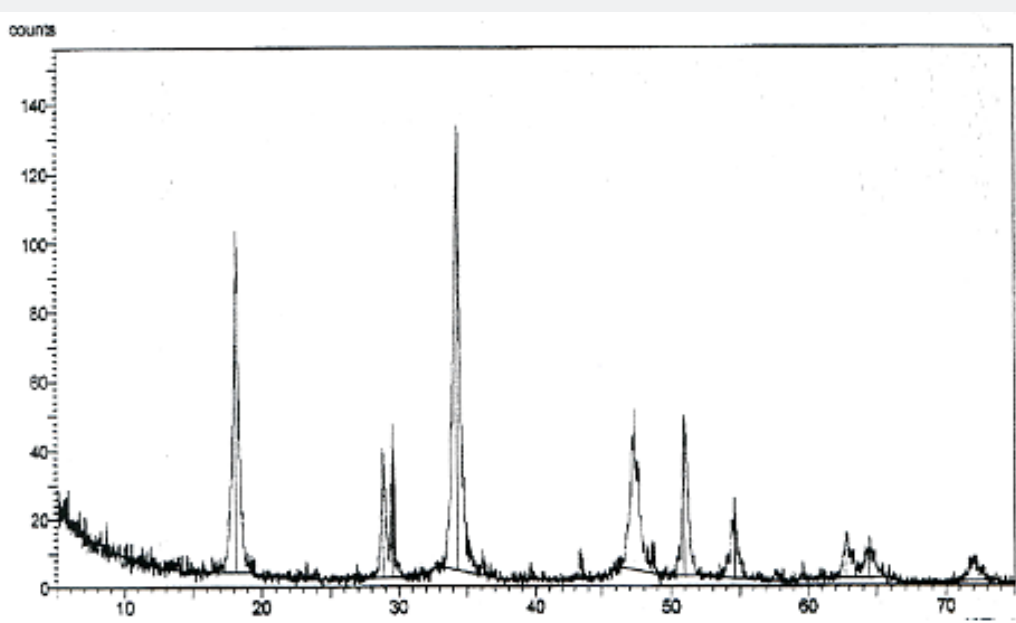

Figure 1: Diffractogramme of the powder lime by X-ray.

\section{Fibers}

Table 2: Chemical analysis of the powder of fibers calcined at $400{ }^{\circ} \mathrm{C}$.

\begin{tabular}{|c|c|c|c|c|c|c|c|c|c|c|}
\hline $\mathbf{S i O}_{2}$ & $\mathbf{A l 2 O}_{3}$ & $\mathbf{F e}_{\mathbf{2}} \mathbf{O}_{\mathbf{3}}$ & $\mathbf{M n O}$ & $\mathbf{M g O}$ & $\mathbf{C a O}$ & $\mathbf{N a}_{\mathbf{2}} \mathbf{O}$ & $\mathbf{K}_{\mathbf{2}} \mathbf{O}$ & $\mathbf{T i O}_{2}$ & $\mathbf{P}_{\mathbf{2}} \mathbf{O}_{\mathbf{5}}$ & $\mathbf{P A F}$ \\
\hline 48.04 & 6.12 & 2.51 & 0.05 & 4.88 & 14.21 & 1.81 & 2.8 & 0.42 & 0.45 & 18.08 \\
\hline
\end{tabular}

Table 3: Physical and mechanical properties of the fibers used

\begin{tabular}{|c|c|c|c|}
\hline Apparent volumetric mass & \multicolumn{3}{|c|}{$\rho_{a}=512.21-1088.81 \mathrm{Kg} / \mathrm{m}^{3}$} \\
\hline Absolute volumetric mass & \multicolumn{3}{|c|}{$\rho_{s}=1300-1450 \mathrm{Kg} / \mathrm{m}^{3}$} \\
\hline \multirow{2}{*}{ Tensile strength [MPa] } & $\mathrm{L}=100 \mathrm{~mm}$ & $\mathrm{~L}=60 \mathrm{~mm}$ & $\mathrm{~L}=20 \mathrm{~mm}$ \\
\hline & $170 \pm 40$ & $240 \pm 30$ & $290 \pm 20$ \\
\hline Failure of deformation & \multicolumn{3}{|c|}{$\mathrm{d}=0.232$ (diameter of fibers $8 \mathrm{~mm}$ ) } \\
\hline Humidity rate & \multicolumn{3}{|c|}{$\mathrm{w}=9.5-10.5 \%$} \\
\hline Rate of Absorption (after 24 H) & \multicolumn{3}{|c|}{$\mathrm{TA}=96.83-202.64 \%$} \\
\hline Diameter (fibers used) & \multicolumn{3}{|c|}{$\mathrm{d}=$ varied between $0.2-1 \mathrm{~mm}$} \\
\hline
\end{tabular}

The fibers used are vegetable fibers of DOKAR of date palm in the region of Ouargla. The Spectrochemical Analysis of the powder of the fibers after calcination at $400{ }^{\circ} \mathrm{C}$ gave the following elements [2] (Table 2 \& 3).

The fibers used with the following characteristics [3].

\section{Plaster}

The used plaster is a local product taken from the career of oasis in Ghardaïa. It is available in the market. The chemical analysis is summarized in the Table 4.

Table 4: Chemical analysis of plaster.

\begin{tabular}{|c|c|c|c|c|c|c|c|c|c|}
\hline Constituents & $\mathbf{S i O}_{2}$ & $\mathbf{A L}_{2} \mathbf{O}_{\mathbf{3}}$ & $\mathbf{F e}_{2} \mathbf{O}_{\mathbf{3}}$ & $\mathbf{C a O}$ & $\mathbf{M g O}$ & $\mathbf{S O}_{2}$ & $\mathbf{N a}_{\mathbf{2}} \mathbf{0}$ & $\mathbf{K O}$ & $\mathbf{C L}$ \\
\hline Percentage (\%) & 0.70 & 0.10 & 0.08 & 32.15 & 0.53 & 44.95 & 0.09 & 0.03 & 0.002 \\
\hline
\end{tabular}

We can summarize certain essential properties in the Table 5, to identify the plaster.

Table 5: Essential Properties of plaster.

\begin{tabular}{|c|c|}
\hline Apparent volumetric mass $\left(\mathrm{kg} / \mathrm{m}^{3}\right)$ & $840-915$ \\
\hline Absolute volumetric mass $\left(\mathrm{kg} / \mathrm{m}^{3}\right)$ & $1100-1300$ \\
\hline Refusal of sieve $800 \mu \mathrm{m}$ & $2.60 \%$ \\
\hline Refusal of sieve $200 \mu \mathrm{m}$ & $14.20 \%$ \\
\hline Finesse following the method of Blaine in $\mathrm{cm}^{2} / \mathrm{g}$ & $1500-8000$ \\
\hline
\end{tabular}




\section{Civil Engineering Research Journal}

\begin{tabular}{|c|c|c|}
\hline \multicolumn{1}{|c|}{ Setting time (E/P=0.6) } & Beginning(min) & 7 \\
\cline { 2 - 3 } & End(min) & 3.48 \\
\hline \multirow{2}{*}{ Flexural strength (E/P=0.6) $[\mathrm{MPa}]$} & $1 \mathrm{~h}$ & 3.73 \\
\cline { 2 - 3 } & $24 \mathrm{~h}$ & 3.99 \\
\cline { 2 - 3 } & 7 days & 8.51 \\
\hline \multirow{2}{*}{ Compressive strength $(\mathrm{E} / \mathrm{P}=0.6)[\mathrm{MPa}]$} & $1 \mathrm{~h}$ & 9.27 \\
\cline { 2 - 3 } & $24 \mathrm{~h}$ & 10.11 \\
\hline
\end{tabular}

\section{Formulation of Plaster Mortar with Fiber}

The determination of the composition of mortar plaster reinforced with fibers of date palm, we used the same composition with the classic mortar, so we take the following composition:

a) We take the report $\mathrm{E} /(\mathrm{P}+\mathrm{S})=0,6$;

b) The report of $\mathrm{S} / \mathrm{P}$ is set to the value 0,5 ;

c) They add $6 \%$ limes air as retarding of setting time.

d) After the preparation of fibers of date palm, we respect the recommendations of Kriker [2], for this, the fibers used are treated in the water, then dried in the free area.

e) The mixing is carried out in the following way:

f) We are mixing first of all the Sand and fibers to sec;

g) The plaster is added, while blending it well with the sand and fibers;

h) It adds the mixing water and lime and malaxant well the mixture.

\section{Confections of samples and storage conditions}

After the mixing, it fulfils the mussels to reason of two layers and vibrate the mortar using a rod to ensure a good distribution and a proper orientation of the fibers, and finally grind and smooth the surface of the mortar. The test pieces are assembled, they are placed in the open air in the laboratory. After 24 hours, these are removed and placed in free air at a temperature of $(25$ ${ }^{\circ} \mathrm{C} \pm 1{ }^{\circ} \mathrm{C}$ ) up to the time of the test, this procedure is made for all the compositions and for all tests.

The samples used are $(4 \times 4 \times 16) \mathrm{cm}^{3}$ for the following tests:

a) Determining the density;

b) Absorption of water ;

c) Tensile strength ;

d) compression strength ;

\section{Composition of mortar of plaster reinforced by fibers of date palm}

To get a good composition of mortar plaster reinforced with fibers of date palms, we follow the following steps: a) First of all, we use the same composition of pate of mortar base of plaster, which we have obtained in the step above.

b) As regards the fibers we tried to determine,

i. First of all the mass fraction optimal fiber to introduce in the mortar of plaster using the fibers of the date palm to a constant length $\mathrm{L}=10 \mathrm{~mm}$ and by increasing the dosage of fiber from $0 \%$ to $2 \%$ with a step of $0.5 \%$ by mass.

ii. And then, the optimal length for the optimal fraction that we found previous for each length, $10 \mathrm{~mm}, 20 \mathrm{~mm}$, $30 \mathrm{~mm}$, et $40 \mathrm{~mm}$.

Laying all tests, that we were conducting, keep well the workability of dough into court of setting time. Because the addition of plant fibers to a mineral matrix leads to a decrease in workability.

All the samples are retained in the ambient air of the laboratory until the age of 14 days.

\section{Results and discussions}

\section{Variation of physical and mechanical properties of the Mortar plaster reinforced by fibers of length of $10 \mathrm{~mm}$ with different percentages}

The results of the variation of physical and mechanical properties of the Mortar plaster reinforced by various dosage of fiber are.

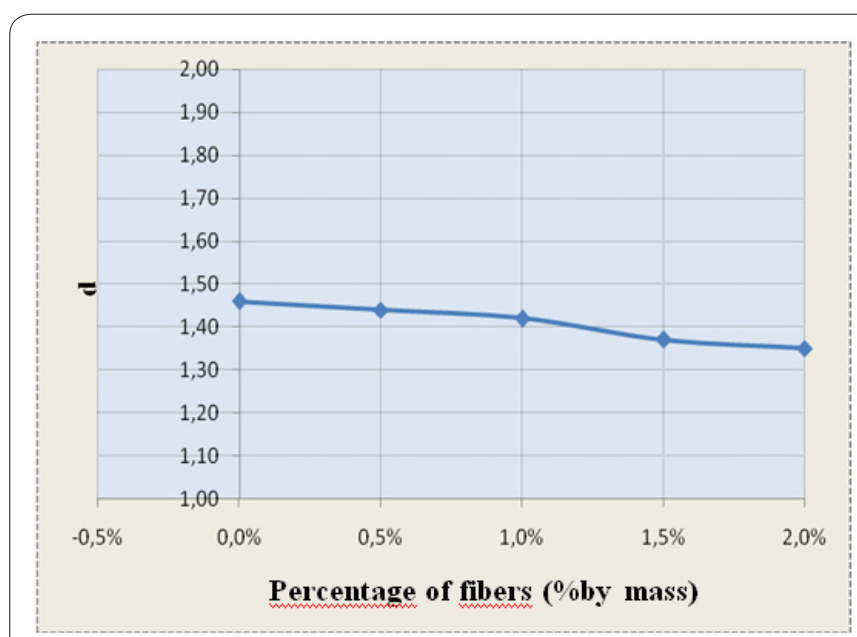

Figure 2: Variation of density of mortar of plaster in function of the percentage by mass of fibers. 
The density: From Figure 2, we notice that density decreases slightly with increasing the dosage of fiber, which can be explained by the increase in the volume of void created by the incorporation of fibers where obtaining a less dense plaster mortar. This result is in agreement with the research of Djoudi [1].

The absorption of water: Figure 3 illustrates the evolution of absorption of water for a mortar of plaster reinforced with fibers of a date palm, it is clearly visible that the absorption of water increases according to the increase in the percentage of the fiber plant, this is due to the volume of the high vacuum created by the addition of the fibers and by the nature of the fibers themselves.

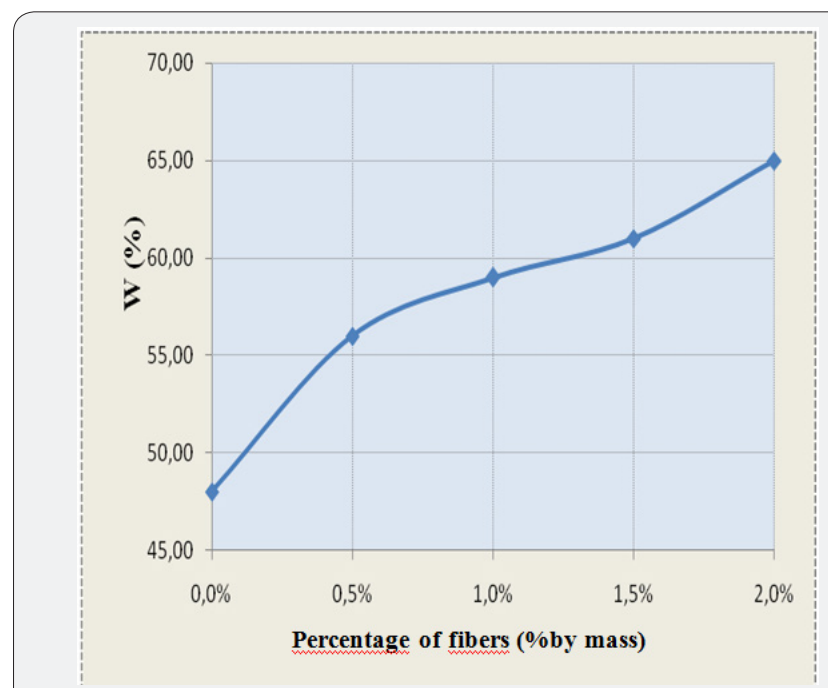

Figure 3: Variation of water absorption of mortar of plaster in function of the percentage by mass of fibers.

These results correspond to the results obtained by Djoudi [1] in his research on concrete plaster reinforced with fiber of date palm, it has been found that incorporation of fibers increases the water absorption of concrete plaster.

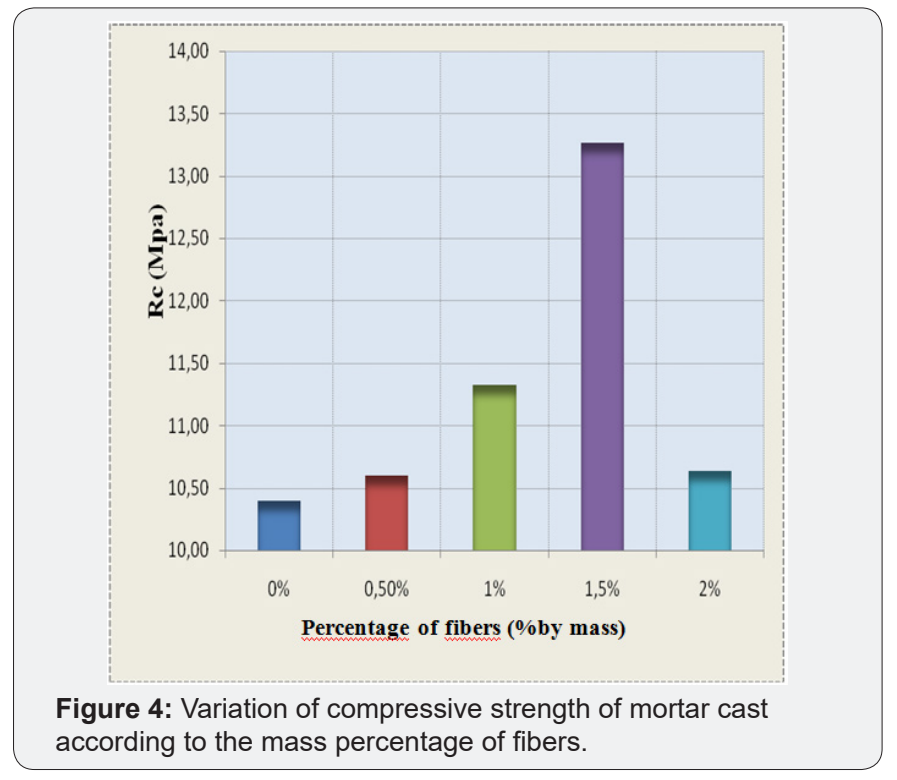

Compression strength: According to Figure 4, it can be seen that between $0 \%$ and $1 \%$ a slight increase in the compressive strength, then $1,5 \%$ an acute increase in the compressive strength and after this percentage a Fall in compressive strength.

the increase in the compressive strength of mortar, plaster reinforced by fiber of the palm, from the non fibré mortar can be explained that the fibers in the percentage of fat play a role in normal concrete aggregate, and the fall that occurred after this increase, we can judge that the addition of fiber disruption the mortar with mineral skeleton void inside the dough and increasing its porosity, with minimal resistance. These findings are in agreement with most of the research conducted, as Kriker [2], in its research on the concrete reinforced by fibers of palm.

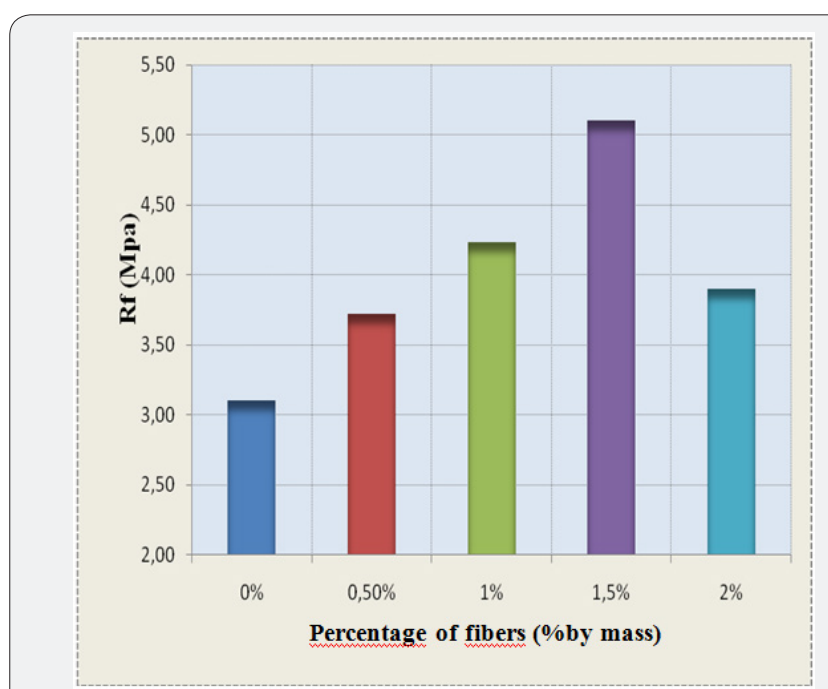

Figure 5: Variation of the flexural strength of plaster mortar as a function of the percentage by mass of fibers.

The flexural strength: Figure 5 shows that the flexural strength increases with increasing fiber dosage, reaches a maximum value for the $1.5 \%$ fiber percentage. Beyond this percentage, it drops and this is due to the poor distribution of the fibers in the pulp due to an excess of fibers. This is the same interpretation revealed by Hernandez-Olivares $F$ [4] in his research on plaster reinforced with sisal fibers. It can also be said that there is a possibility of seeing the phenomenon of slippage of the fibers between them in the course of this test.

Recapitulation: A quick review of the previous graphs, we find that the percentage of $1.5 \%$ gives the best results from the point of view of compressive and flexural strength, as well as water absorption and density. And with regard to the workability of plaster mortar, this percentage gives good workability and easy implementation.

\section{Variation of physical and mechanical properties of the Mortar plaster reinforced by different lengths of fibers for a percentage of $\mathbf{1 . 5 \%}$ of fibers}

The results of the Variation of the physical and mechanical properties of the mortar of plaster reinforced by different length of fibers are: 


\section{Civil Engineering Research Journal}

The density: Figure 6 shows that the density decreases rapidly with the increase of the length of fibers, this is due to the fact that the incorporation of fibers in the pulp leads to voids within the dough, and the percentage of voids is important for wavelengths important for fiber. The most sought after literatures reveal this observation.

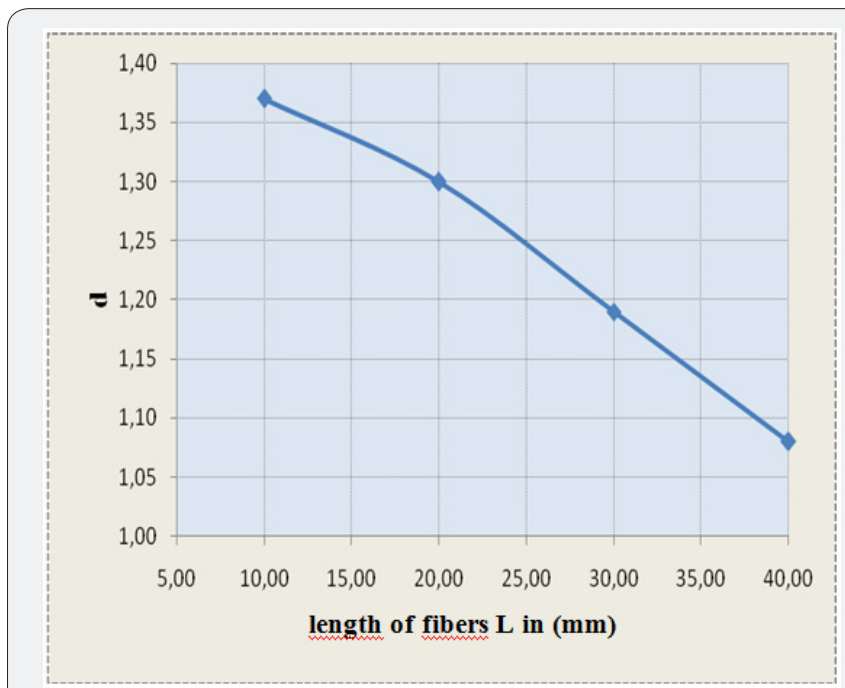

Figure 6: Variation of density of mortar of plaster in function of different fiber lengths.

The absorption of water: According to Figure 7, it can be seen that the absorption of mortar water increases with increasing fiber lengths, it is important for long lengths, this is due to the high void volume created by the addition of fibers from which maximum water absorption.

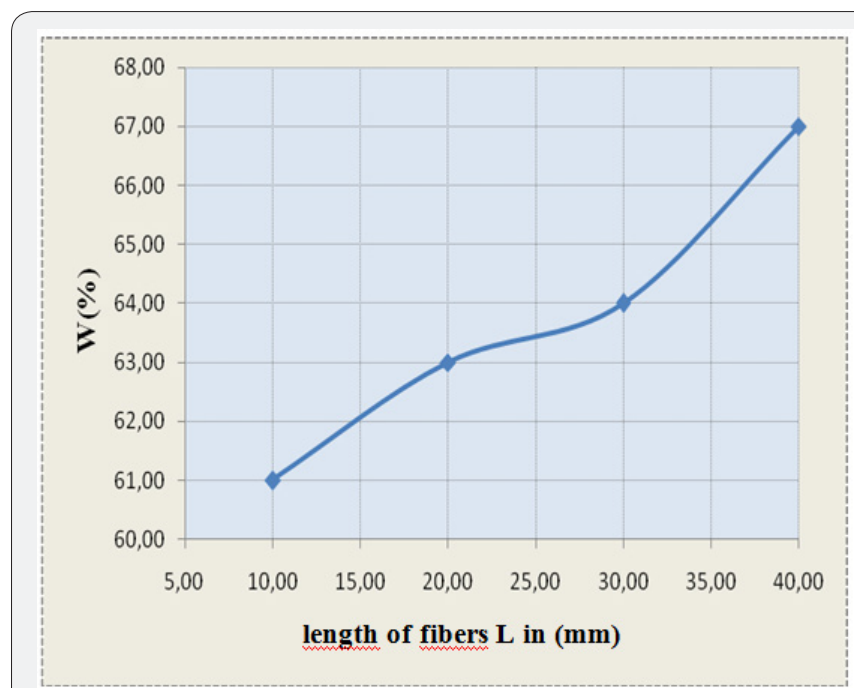

Figure 7: Variation of the water absorption of plaster mortar as a function of different fiber lengths.

According to Guermiti [5], the percentage of water absorption after 24 hours of immersion is of the order of 6.59 per cent for the ordinary concrete, and increases for concretes of fibers in function of the dosing and length arriving to (6.64 $6.76 \%$ ) for the concrete which contains 0.5 to $1 \%$ of short fibers, (6.70-6.86\%) for the concrete which contains 0.5 to $1 \%$ of long fibers.
Compression strength: We note, from Figure 8, the increase in the length of the reinforcing fiber does not remarkably develop the compressive strength of the mortar, which has been observed from the results obtained. For our mortar there is a slight improvement in the compressive strength of the fibers with a length of $10 \mathrm{~mm}$ and reaches a maximum for fibers with a length of $20 \mathrm{~mm}$ and then there is a slow decrease for fibers of length $30 \mathrm{~mm}$ and $40 \mathrm{~mm}$. This finding is due to the influence of length of the fibers on the workability by their entanglements. The various researchers agree that the fibers do not provide appreciable improvement in compression In some cases, there is a slight increase, in others a slight decrease. This decrease may be caused by poor compactness due to excess fiber, or poor composition. For example, Djoudi [1] found that the incorporation of date palm fibers into gypsum concrete provides a slight improvement when the percentage of fibers is low and a decrease for the higher percentages.

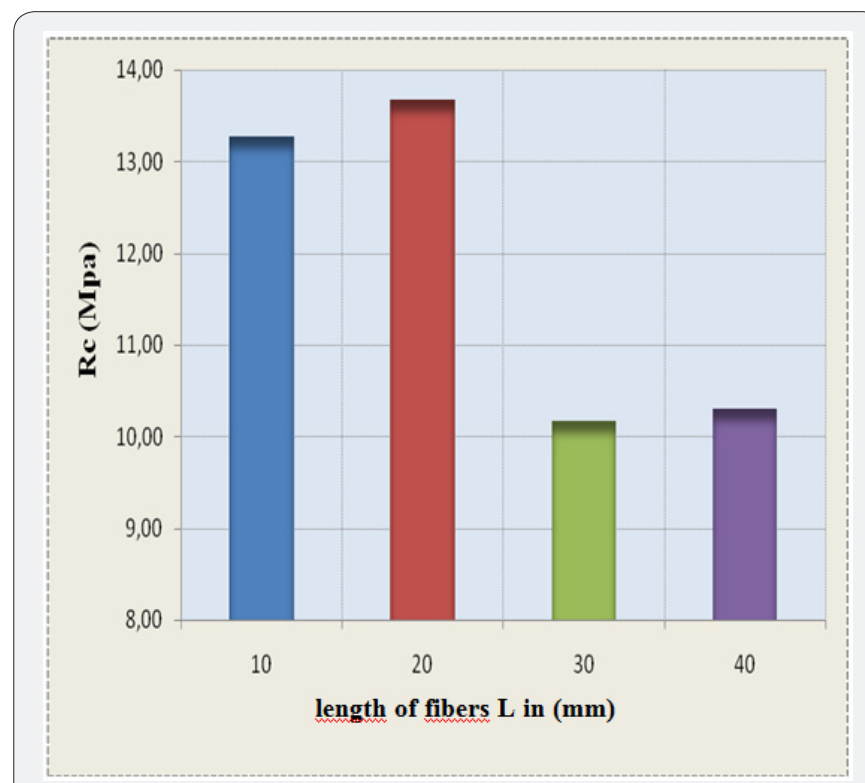

Figure 8: Variation in the compressive strength of plaster mortar as a function of different fiber lengths.

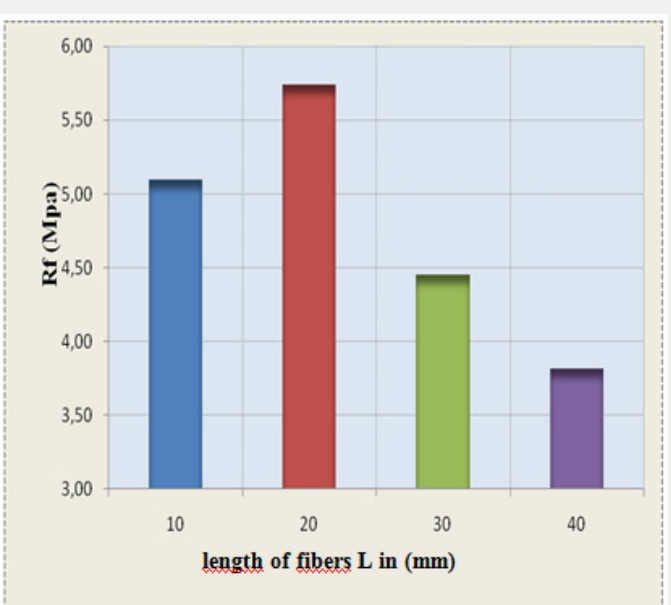

Figure 9: Variation of the flexural strength of mortar plaster in function of different fiber lengths. 


\section{Civil Engineering Research Journal}

The flexural strength: Figure 9 shows the influence of the length of the fibers on the flexural strength of fiber mortar. First of all, we note clearly that The flexural strength considerable increases with all the lengths of the fibers. A net improvement for the fibers of lengths of $10 \mathrm{~mm}$ and the resistance reaches the maximum for the lengths of $20 \mathrm{~mm}$. After, a decrease in the resistance for lengths $30 \mathrm{~mm}$ and $40 \mathrm{~mm}$, which can be always translates by the loss of manoeuvrability that due to a exercised of fiber and a poor distribution of fibers in the pate increasing porosity and consequently a decrease in the flexural strength.

By simulation, we find that the mortar of the plaster has the same properties of the cement mortar. That appears in the research on the cement mortar reinforced by strip of wood. It was found that, for a mortar to $2 \%$ had a flexural strength that $3 / 10$ mortar witness that is to say three times more.

Recapitulation: The fibers of length $20 \mathrm{~mm}$ give the best results of resistance to compression and flexion. As these fibers give acceptable results in the density and absorption of water. As for the handling, the mortars reinforced by the fibers of length of $20 \mathrm{~mm}$ have a good workability and facilitates the implementation.

\section{Conclusion}

After all those previous tests we've had. We can say that we have achieved an optimal composition for a mortar of plaster reinforced with fibers of date palm, which meet the different mechanical and physical characteristics and the requirements necessary for a building material, such as; the workability, to compression and flexural strengths, water absorption and density.

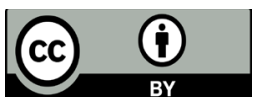

This work is licensed under Creative Commons Attribution 4.0 License DOI: 10.19080/CERJ.2018.04.555650
Our composition of mortar plaster reinforced with fiber, on which we did durability testing, will be as follows:

a) We take the report $\mathrm{E} /(\mathrm{P}+\mathrm{S})=0,6$;

b) The report $\mathrm{S} / \mathrm{P}$ is set to the value 0,5 ;

c) We add 6\% air lime as a retardant of setting time.

d) For fibers: get the lengths $\mathrm{L}=20 \mathrm{~mm}$ fibers, and a percentage mass equal to $1.5 \%$.

The plaster mortar based on dune sand reinn forced with date palm fibers seems to have a great future in certain areas, the technical and economic advantages of this material allow for an important development for the future.

\section{References}

1. Djoudi Amina (2001) Caractérisation structurale et rhéologique des bétons de plâtre et leur renforcements par les fibers végétales du palmier dattier. Thèse de magister, Universite De Laghouat.

2. Kriker A (2005) Caractérisation des fibers de palmier dattier et propriétés des bétons et mortiers renforcés par ces fibers en climat chaud et sec. Thèse de doctorat d'état, ENP, Alger.

3. Mokhtari Abdessamed (2006) Influence des ajouts de fines minérales sur les Performances Mécaniques des Bétons Renforcés de Fibers Végétales de Palmier Dattier. Thèse de magister, Université De Ouargla.

4. Hernandez-Olivares F, Oteiza I, de Villanueva L (1992) Experimental analysis of toughness and modulus of rupture increase of sisal short fiber reinforced hemihydrated gypsum. Composite Structures 22(3):123-137.

5. Guermiti Laid (2013) Contribution a l'amélioration de certaines caractéristiques du béton de structure à base de sable de dune corrigé et renforcé par des fibers métalliques. Thèse magistère, Université De Ouargla 5(1).

\section{Your next submission with Juniper Publishers will reach you the below assets}

- Quality Editorial service

- Swift Peer Review

- Reprints availability

- E-prints Service

- Manuscript Podcast for convenient understanding

- Global attainment for your research

- Manuscript accessibility in different formats

( Pdf, E-pub, Full Text, Audio)

- Unceasing customer service

Track the below URL for one-step submission https://juniperpublishers.com/online-submission.php 